\title{
EVERY DAY STUDENTS IN SCHOOLS MATTER-REASONS FOR NOT ATTENDING THE SCHOOL: EVIDENCE FROM ADVANCED LEVEL STUDENTS
}

\author{
M. N. F. Shakira \& N. Kengatharan* \\ kenga@univ.jfn.ac.lk \\ Department of Human Resource Management \\ University of Jaffna
}

\begin{abstract}
The reason for students' absenteeism may vary across nations depending on country and cultural differences. Studies on student's absenteeism that have been investigated in the west are reflective of such cultural contexts and therefore, the finding can not be directly applied to another cultural context. There is a dearth of such studies in Asian and other similar developing countries. Consequently, the present study aims to discover factors determining students' absenteeism in Sri Lanka. Strongly based on philosophical assumptions, the present study mainly employed a survey research strategy and data were primarily garnered from a self-administrated questionnaire. A total of 129 Advanced level students representing Arts and commerce streams were conveniently selected from five schools, namely KG/MW Baduriya Central College, KG/MW Zahira National School, KG/MW Mayurapada National School, KG/MW Nooraniya Muslim Vidhyalaya and KG/MW Mederigama Central College located Mawanella Zone in Sabaragamuwa province. The study revealed six factors determining students' absenteeism, named student-preference, teacher and subject, physical and mental capabilities, non-collegiate, classroom facility and personal factors. Needless to say, the current study made several theoretical and practical implications.
\end{abstract}

Keywords: students' absenteeism, student-preference, physical and mental capabilities, non-collegiate, classroom facility, teacher and subject

\section{Introduction}

There was a piece of shocking news that 59 million children of primary school were out of school; 52 per cent of them were girls (Zahrah, 2016). About one-third of the world's out-of-school children live in West and Central Africa; about one fifth is in 
Eastern and Southern Africa. In South Asian region, Pakistan confronts the huge challenge in terms of both the proportion ( 28 per cent) and number (5.5 million) of children out-of-school. Nonetheless, the number of out-of-school children of primary school has scaled down globally from 99 million to 59 million between 2000 and 2013, progress has stalled since 2007. Moreover, students' attendance is less than 80 per cent in 25 countries concentrated mainly in the West and Central Africa and in South Asia. In many countries, children from the poorest 20 per cent of the population are less likely to attend school than those who are better off, with each successive quintile having a higher average attendance. The total number of out-of-school children and youth has declined by a little more than 1 million per year since 2012 . Some 63 million, or $24 \%$ of the total, are children of primary school age (about 6 to 11 years old); 61 million, or $23 \%$ of the total, are adolescents of lower secondary school age (about 12 to 14 years old); and 139 million, or $53 \%$ of the total, are youth of upper secondary school age (about 15 to 17 years old). Students' irregularity has been noticed in many countries (see Wadesango et al., 2011) and studies have investigated to identify reasons for students' absenteeism across several countries, for instance, Belita, Mbindyo, and English (2013); Burke (2010); Dashputra, Kulkarni, Chari, and Date (2015); and Wadesango et al. (2011). To the best of our knowledge, no systematic studies have attempted to identify the reasons for students' absenteeism in Sri Lanka to date.

Previous studies that have been investigated in the West identified many reasons for students' absenteeism, nonetheless, the findings are not directly applicable to another cultural context. The students' absenteeism is country-specific macro-environmental factors such as poverty, educational policies, culture etc. Succinctly, the reasons for students' absenteeism in developed countries might be different in case of developing countries. Therefore, there is a compelling need for finding out the reasons for students' absenteeism in Sri Lanka and other similar developing countries. Consequently, the present study aims to identify factors determining students' absenteeism among advanced level students in Sri Lanka.

\section{Literature Review}

Student absenteeism is a period of time when a student does not attend school (Teasley, 2004). Remarkably, continuous absenteeism among students has caused serious problems in many countries. Therefore, there is a need for identifying factors determining student-absenteeism prior to making any policy decisions and strategies. Earlier studies conducted in many countries have reported a range of factors 
contributing to students' absenteeism such as: family health, low income, part-time working, poor school climate, sick, drug and alcohol use, lack of school fees, student delinquency and truancy, time out on games and sports, parents' education levels, harassment, bullying, snow, rain, lack of transport and community attitudes towards education (Dashputra et al., 2015; Balfanz \& Byrnes, 2012; Henry, 2007; Massingham \& Herrington, 2006; Roby, 2003; Teasley, 2004). Interestingly, Lin (2010) found that boring or uninteresting, unimpressive style of teaching kills the interest of the students' attendance at school. Similarly, Kube and Ratigan (1992) found that good weather, vacations and peer group pressure affects students' attendance. Schumulian and Coetzee's (2011) study reveals traffic and oversleeping are the causes of students' absenteeism. What was the overriding importance is that the reasons for students' absenteeism are different from country to country, family to family and even at individual student-level. For instance, cultural values such as early and forced marriage, attitudes of family and community towards girls' education, lack of female teachers could affect students' attendance (McElroy, 2013). Though, from a large pool of empirical studies, the reasons for students' absenteeism can be subsumed under three categories: Student-related factor, teacher-related factor and environmental-related factor.

\section{Student-Related Factors}

Many studies that have been undertaken in the sphere of students' regularity to the schools have reported a list of student - related factors determining Students' absenteeism such as sickness, family health, low income, peer group pressure, drug and alcohol use, tired/sleepy, poor language, peer pressure, student's socioeconomic status, parents' education levels, homesick, family-related problem/breakup, not interested subjects, groupism, extracurricular work, not allowing late arrivals of the student, and exam preparation (Dashputra et al., 2015; Henry, 2007; Kube \& Ratigan, 1992; Massingham \& Herrington, 2006; Teasley, 2004). Notably, Rao, Valleswary, Nayak, and Rao's study (2016) disclosed that laziness, taking part in extracurricular activities (cultural activities, sports), food and water-related problems and preparing for internal assessment examinations are the causes of students' absenteeism and their findings are similar to that of BinSaeed, Al-Otaibi, Al-Ziyadi, Babsail, and Shaik'sstudy (2009) that mostly attributed the students' absence to the preparation of the exam. Another study undertaken by Teasley (2004) found that family health, low income, poor school climate, drug and alcohol use, transportation problems, and community attitudes towards education cause the students' absenteeism. Intriguingly, 
Williams (2001) suggests that the involvement of fun activities and socialising with their peers outside of school develop students' absenteeism. Civil strife and natural disasters (Dashputra et al., 2015), and illness and oversleeping (Schumulian \& Coetzee, 2011) are also other causes of students' absenteeism. The seminal study of Paisey and Paisey (2004) reported that students' absenteeism is because of part-time work, illness and other personal reasons. Succinctly, as discussed above, studentrelated factors of absenteeism are subjected to county-culture specific nature.

\section{Teacher-Related Factors}

Based on the empirical evidence, a large number of factors determining students' absenteeism are related to teacher-specific. More interestingly, Dashputra et al.'s (2015) study claimed that teachers fail to motivate the students and consequently, those students felt studying at home is better rather attending the school. The factors related to teacher-specific include teacher attitude, teaching methodology, teacher approach to the subject, teaching quality, teaching contents, lengthy classes, lack of clarity about the topic among teachers, teacher attendance, boring or uninteresting and unimpressive style of teaching and poor feedback (Bati et al., 2013; Dashputra et al., 2015; Devadoss \& Foltz, 1996; Fernandes, Maley, \& Cruickshank, 2008; Gump, 2006; Lin, 2010; Massingham \& Herrington, 2006; Ruiz, Mintzer, \& Leipzig, 2006). For instance, Rao et al. (2016) suggest that small classes, active learning methods and timely feedback alleviate students' absenteeism at school and the findings are in line with the earlier study of Burke (2015) who confirmed that the improving teaching styles and methods weaken students' irregularity in schools. The study of Rodriguez et al. (2003) revealed that the proximity of exams results in poor attendance of the students. Based on the collection of empirical studies, we have identified many factors are prone to Students' absenteeism.

\section{Environment-Related Factors}

The third form of the factors determining students' absenteeism is named "environmental-related factors". By and large, environmental-related factors include poor ventilation, overcrowding, sitting arrangement, insufferably hot, noise, spatial elements, classroom equipments (e.g. desks, chairs, rugs, chalkboards, tack boards, easels, counters and computer equipment), classroom acoustics and poor infrastructure (Dasputra et al., 2015; Fisher \& Larkin, 2008; Haertel, Walberg, \&Haertel, 1981; McElroy, 2003; Rao et al., 2016; Walker, Colvin, \& Ramsey, 1996).For instance, Haertel et al. (1981) disclosed that the students' perception of the 
classroom environment is an important factor promoting students' attendance and some others observed that the students are not attending the school owing to poorly ventilated classrooms and uncomfortable sitting arrangement (Dasputra et al., 2015). Remarkably, many research scholars support the notion that well-structured classrooms enhance students' academic and behavioural outcomes (McElroy, 2003; Savage, 1999; Stewart, Evans, \& Kaczynski, 1997; Walker et al., 1996) and thus, the structure of the classroom is described as "silent curriculum" (Taylor \&Vlastos, 2009).

In summary, all the factors determining students' absenteeism have been predominantly identified based on Western studies. Nonetheless, studies on students' absenteeism are scant in developing countries. Since students' absenteeism is countryspecific nature, the present study attempts to answer an unanswered question left by earlier studies that why students are not regularly attending to the school in Sri Lanka.

\section{Methods}

Based on the ontological and epistemological assumptions, the present study adopts a survey strategy with a deductive approach in a cross-sectional time horizon. The first author has actively engaged with the data collection. A total of 129 Advanced level students representing Arts and commerce stream were conveniently selected from five schools, namely KG/MW Baduriya Central College ( $\mathrm{n}=31$ ), KG/MW Zahira National School ( $\mathrm{n}=33$ ), KG/MW Mayurapada National School ( $\mathrm{n}=22), \mathrm{KG} / \mathrm{MW}$ Nooraniya Muslim Vidhyalaya $(n=23)$ and KG/MW Mederigama Central College $(n=20)$ located Mawanella Zone in Sabaragamuwa province. The majority of the students were males $51.2 \%(n=66)$ and the remaining $48.8 \%$ were females $(n=63) .60$ students represent the commerce stream and the remaining students from the Arts stream. Interestingly, the highest number of students $(41.1 \%)$ walks to the school indicatingthe closeness of students' residence to the schools.

\section{Instrument}

From the empirical studies and interviews with students, the most appropriate 27 items' scale was employed to identify the factors contributing to Students' absenteeism (see Dashputra et al., 2015). Some sample items include 'I stay at home to study for term exams', 'I don't attend school when I have tuition classes on weekdays', 'I don't like to attend school when I'm not interested in the topic', 'my teacher is boring and I can't understand what he/ she is speaking', 'I don't like to attend school when the 
subject is boring', 'I prefer to attend tuition classes rather than attending school', 'studying at home is better rather than attending school', 'teacher is targeting me in class so I do not attend school', and 'I don't like to attend school when I don't like the tone of teacher'. The items were measured with a five-point Likert scale where students were asked to indicate their degree of agreement on each statement provided.

\section{Results}

Since the items measuring student's absenteeism were emerged from culturally different contexts, factor analysis was warranted to identify underlying factor structure of the latent constructs (Hair, Black, Babin, \& Anderson, 2014). KaiserMeyer-Olkin (KMO) is the test which tells about the appropriateness of factor analysis and sampling adequacy. The KMO value lies between zero and one, and the value closer to one indicates that the data set is appropriate for factor analysis. It is also assumed that all the variables are somewhat correlated to each other and this assumption can be checked by Bartlet's sphericity test.

\section{Table 1: KMO and Bartlett's Test}

\begin{tabular}{lll}
\hline KMO and Bartlett's Test & \\
\hline Kaiser-Meyer-Olkin Measure of Sampling Adequacy. & .739 \\
Bartlett's Test of Sphericity & Approx. Chi-Square & 694.26 \\
& df & 210 \\
& Sig. & .000 \\
\hline
\end{tabular}

As can be seen in Table 1, the KMO value is 0.739 indicating that the factor analysis is relevant with this data set, Kaiser recommends values between 0.7 and 0.8 are good. In addition, the significance of Bartlet's sphericity test is 000 which also confirms the suitability of the data set for the factor analysis. Now, one of the key concerns of factor analysis is to determine the number of factors to be extracted and thus principal component analysis (PCA) was employed to identify the number of factors for the causes of absenteeism.

Table 2 below summarizes the results of the extraction of the factors and the percentage of variance explained by each of these factors. The factors were extracted if eigenvalue is greater than one (Kaiser's criterion), and as can be seen in the same Table, the first six factors were extracted explaining $58.45 \%$ variance. The variance in order of first to sixth factors are as follows: $19.91 \%, 13.44 \%, 7.92 \%, 6.62 \%, 5.34 \%$ and $5.21 \%$. 
Table 2: Factor extraction - Kaiser's criterion

\begin{tabular}{|c|c|c|c|c|c|c|c|}
\hline \multirow{2}{*}{ 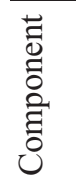 } & \multirow[b]{2}{*}{ Total } & \multicolumn{2}{|c|}{ Initial Eigenvalues } & \multicolumn{3}{|c|}{$\begin{array}{c}\text { Extraction Sums of Squared } \\
\text { Loadings }\end{array}$} & \multirow{2}{*}{$\begin{array}{l}\text { Rotation Sums } \\
\text { of Squared } \\
\text { Loadings }^{\mathrm{a}} \\
\text { Total }\end{array}$} \\
\hline & & $\%$ of Variance & Cumulative $\%$ & Total & $\%$ of Variance & Cumulative \% & \\
\hline 1 & 4.182 & 19.914 & 19.914 & 4.182 & 19.914 & 19.914 & 2.673 \\
\hline 2 & 2.823 & 13.444 & 33.359 & 2.823 & 13.444 & 33.359 & 2.803 \\
\hline 3 & 1.664 & 7.924 & 41.282 & 1.664 & 7.924 & 41.282 & 2.493 \\
\hline 4 & 1.390 & 6.620 & 47.903 & 1.390 & 6.620 & 47.903 & 1.500 \\
\hline 5 & 1.120 & 5.335 & 53.237 & 1.120 & 5.335 & 53.237 & 2.482 \\
\hline 6 & 1.094 & 5.208 & 58.446 & 1.094 & 5.208 & 58.446 & 1.948 \\
\hline 7 & .994 & 4.735 & 63.181 & & & & \\
\hline ..... & $\ldots \ldots$. & ........ & ....... & & & & \\
\hline 21 & .293 & 1.394 & 100.000 & & & & \\
\hline
\end{tabular}

Extraction Method: Principal Component Analysis.

a When components are correlated, sums of squared loadings cannot be added to obtain a total variance.

Cattell's Scree test (1966) is another extraction technique, derived by plotting Eigenvalues (on Y- axis) against the number of factors (on X-axis).The graph is known as a scree plot. Cattell recommends that the cut off point for extracting factors should be at the point of inflexion. The point of inflexion is where the curve becomes horizontal and meets the vertical and horizontal lines. Only factors to the left of the point of inflexion can be retained. As shown in figure 1, the point of inflexion is at the seventh component confirming that only six components can be retained in line with the results of the application of Kaiser's criterion.

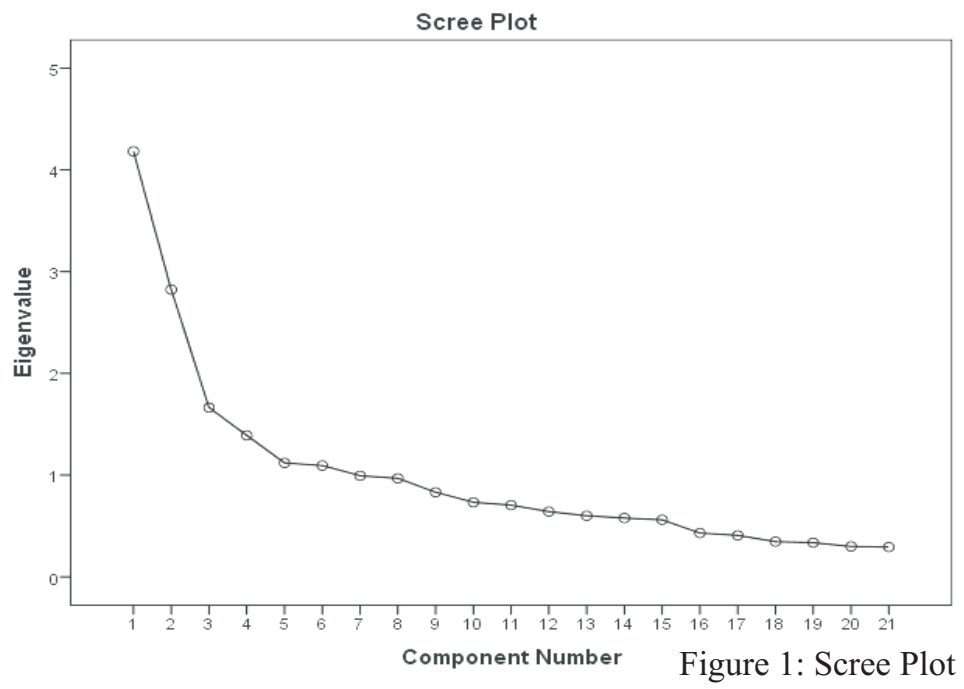


The below set of tables present the pattern matrix derived from direct oblimin with the Kaiser Normalization rotation (KNR). The Table clearly shows the items loaded onto each factor.

\section{Factor 1}

Table 3 shows the first factors consist of three items, loadings range from .487 to .764. Since the items describe students" interest and choice, the factor is named as "StudentPreference".

\section{Table 3: Factor 1}

\begin{tabular}{lcc}
\hline \multicolumn{1}{c}{ Variables (Items) } & Loading & Factor name \\
\hline $\begin{array}{l}\text { I stay at home to study for term } \\
\text { exams }\end{array}$ & .764 & \\
$\begin{array}{l}\text { I don't attend school when I have } \\
\text { tuition classes on week days }\end{array}$ & .749 & $\begin{array}{c}\text { Student - } \\
\text { Preference }\end{array}$ \\
$\begin{array}{l}\text { I don't like to attend school when I'm } \\
\text { not interested in the topic }\end{array}$ & .487 & \\
\hline
\end{tabular}

\section{Factor 2}

Factor 2, as shown in Table 4 consists of six items and the loadings range from .424 to .708. Since the items describe teacher and subject-related matters, the factor is named as "teacher and subject".

\section{Table 4: Factor 2}

\begin{tabular}{lll}
\hline Variables (Items) & Loading & Factor name \\
\hline $\begin{array}{l}\text { My teacher is boring and I can't } \\
\text { understand whathe/she is speaking }\end{array}$ & .708 & \\
$\begin{array}{l}\text { I don't like to attend school when } \\
\text { the subject is boring }\end{array}$ & .670 & Teacher and subject \\
$\begin{array}{l}\text { I prefer to attend tuition classes } \\
\text { rather than attending school }\end{array}$ & .602 & \\
$\begin{array}{l}\text { Studying at home is better rather } \\
\text { than attending school }\end{array}$ & .594 & .486 \\
$\begin{array}{l}\text { Teacher is targeting me in class so I } \\
\text { do not attend school }\end{array}$ & .424 \\
$\begin{array}{l}\text { I don't like toattend school when I } \\
\text { don't like the tone of teacher }\end{array}$ &
\end{tabular}




\section{Factor 3}

Since the factor 3 concerns with physical and mental related matters, the factor is named as "Physical and mentalcapabilities". The factor 3 consists of 5 items and the loadings range from .406 to .704 .

\section{Table 5: Factor 3}

\begin{tabular}{lcc}
\hline \multicolumn{1}{c}{ Variables (Items) } & Loading & Factor name \\
\hline I can't concentrate in class & .704 & \\
because of feeling sleepy or tired & & \\
I can't wake up early due to late & .626 & \\
night sleep & .593 & $\begin{array}{c}\text { Physical and } \\
\text { mental } \\
\text { capabilities }\end{array}$ \\
I stay at home when I have family & & \\
problems or breakup & .468 & \\
I don't attend school when my & & \\
friends do not & .406 & \\
I don't like to attend school \\
because of the constant noise
\end{tabular}

\section{Factor 4}

The factor 4 consists of only one item with the loading of .779 and the factor is related to the extracurricular activities of students, it is named as "Non-collegiate".

\section{Table 6: Factor 4}

\begin{tabular}{lcc}
\hline \multicolumn{1}{c}{ Variables (Items) } & Loading & Factor name \\
\hline I'm unable to attend & & \\
school when I have & .779 & Non-collegiate \\
to participate in & & \\
extracurricular & & \\
activities & & \\
\hline
\end{tabular}

\section{Factor 5}

As can be seen in Table 7, factor 5 has 4 items describing classroom facilities such as ventilation, sitting arrangement and illumination. The item loadings are ranging from .490 to .594 . Based on the nature of the items, the factor 5 is named as "classroom facility". 


\section{Table 7: Factor 5}

\begin{tabular}{|c|c|c|}
\hline Variables (Items) & Loading & Factor name \\
\hline $\begin{array}{l}\text { I don't like to attend school } \\
\text { because of the uncomfortable } \\
\text { sitting arrangement in the } \\
\text { classroom }\end{array}$ & .594 & Classroom \\
\hline $\begin{array}{l}\text { I don't attend school because of the } \\
\text { poor ventilation in the classroom }\end{array}$ & .585 & facility \\
\hline $\begin{array}{l}\text { I can't see blackboard properly } \\
\text { because of the poor illumination. } \\
\text { So I don't like to attend school }\end{array}$ & .556 & \\
\hline $\begin{array}{l}\text { I don't like to attend school due to } \\
\text { overcrowding in the class }\end{array}$ & .490 & \\
\hline
\end{tabular}

\section{Factor 6}

As can be seen in Table 8, factor 6 consists of 2 items describing personal reasons for not attending the school. The items' loadings range from .642 to .769. The factor 6 is named as "Personal".

\section{Table 8: Factor 6}

\begin{tabular}{lcc}
\hline \multicolumn{1}{c}{ Variables (Items) } & Loading & Factor name \\
\hline $\begin{array}{l}\text { I don't like to attend school } \\
\text { because of the stream I select }\end{array}$ & .769 & \\
$\begin{array}{l}\text { Most probably I don't attend school } \\
\text { when I'm sick }\end{array}$ & .642 & Personal \\
\hline
\end{tabular}

In summary, our analysis produces a six-factor solution for the students' absenteeism. Moreover, an additional analysis of "independent sample t-test" was performed to see gender makes a difference in the reasons for the students' absenteeism. Table 9 shows the mean values for the six factors in terms of male and female. 
Table 9: Group Statistics of absenteeism factors

\begin{tabular}{llcccc}
\hline & \multicolumn{4}{c}{ Group Statistics } & \\
& Gender & $N$ & Mean & $\begin{array}{c}\text { Std. } \\
\text { Deviation }\end{array}$ & Std. Error Mean \\
\hline Studentpreferences(SP) & Male & 66 & 3.823 & .571 & .070 \\
& Female & 63 & 4.143 & .647 & .082 \\
\hline Teacher and subject (TS) & Male & 66 & 3.859 & .545 & .067 \\
& Female & 63 & 4.071 & .531 & .067 \\
\hline Physical and mental & Male & 66 & 3.827 & .580 & .071 \\
capabilities (PM) & Female & 63 & 3.987 & .447 & .056 \\
\hline Non-collegiate(NC) & Male & 66 & 4.030 & .841 & .103 \\
& Female & 63 & 4.175 & .853 & .107 \\
\hline Classroom facility (CF) & Male & 66 & 3.712 & .684 & .084 \\
& Female & 63 & 3.726 & .546 & .069 \\
\hline Personal(P) & Male & 66 & 3.871 & .658 & .081 \\
& Female & 63 & 4.040 & .709 & .089 \\
\hline
\end{tabular}

Table 9: Group Statistics of a As can be seen in Table 9, surprisingly the mean values are greater for females on all six factors than males. Whether the mean differences between male and females are significant or not are presented in Table 10.absenteeism factors.

\section{Table 10: Independent Sample t- Test}

\begin{tabular}{|c|c|c|c|c|c|c|c|c|}
\hline \multicolumn{9}{|c|}{ Independent Samples Test } \\
\hline & & \multirow{2}{*}{\multicolumn{3}{|c|}{$\begin{array}{l}\text { Levene's Test for } \\
\text { Equality of Variance: }\end{array}$}} & \multirow{2}{*}{\multicolumn{4}{|c|}{ t-test for Equality of Means }} \\
\hline & & & & & & & & \\
\hline & & $F$ & Sig. & $t$ & $d f$ & $\begin{array}{l}\text { Sig. (2- } \\
\text { tailed) }\end{array}$ & $\begin{array}{c}\text { Mean } \\
\text { Difference }\end{array}$ & $\begin{array}{l}\text { Std. Error } \\
\text { Difference }\end{array}$ \\
\hline \multirow[b]{2}{*}{ SP } & $\begin{array}{ll}\text { Equal } & \text { variance } \\
\text { assumed } & \end{array}$ & .619 & .433 & -2.980 & 127 & .003 & -.320 & .107 \\
\hline & $\begin{array}{l}\text { Equal variances no } \\
\text { assumed }\end{array}$ & & & -2.971 & 123.38 & .004 & -.320 & .108 \\
\hline & $\begin{array}{ll}\text { Equal } & \text { variance } \\
\text { assumed } & \end{array}$ & 1.680 & .197 & -2.246 & 127 & .026 & -.213 & .095 \\
\hline TS & $\begin{array}{l}\text { Equal variances no } \\
\text { assumed }\end{array}$ & & & -2.247 & 126.94 & .026 & -.213 & .095 \\
\hline \multirow{2}{*}{ PM } & $\begin{array}{ll}\text { Equal } & \text { variance } \\
\text { assumed } & \end{array}$ & 6.831 & .010 & -1.750 & 127 & .082 & -.160 & .091 \\
\hline & $\begin{array}{l}\text { Equal variances no } \\
\text { assumed }\end{array}$ & & & -1.761 & 121.71 & .081 & -.160 & .091 \\
\hline
\end{tabular}




\begin{tabular}{|c|c|c|c|c|c|c|c|c|}
\hline \multirow[b]{2}{*}{$\mathrm{NC}$} & Equal & .136 & .712 & -.968 & 127 & .335 & -.144 & .149 \\
\hline & $\begin{array}{l}\text { Equal variances } \\
\text { assumed }\end{array}$ & & & -.967 & 126.53 & .335 & -.144 & .149 \\
\hline \multirow{2}{*}{$\mathrm{CF}$} & $\begin{array}{ll}\begin{array}{l}\text { Equal } \\
\text { assumed }\end{array} & \text { varian }\end{array}$ & 3.925 & .050 & -.129 & 127 & .898 & -.014 & .109 \\
\hline & $\begin{array}{l}\text { Equal variances } \\
\text { assumed }\end{array}$ & & & -.129 & 123.18 & .897 & -.014 & .109 \\
\hline \multirow{2}{*}{$\mathrm{P}$} & $\begin{array}{ll}\text { Equal } & \text { varian } \\
\text { assumed } & \end{array}$ & .033 & .856 & -1.400 & 127 & .164 & -.168 & .120 \\
\hline & $\begin{array}{l}\text { Equal variances } \mathrm{n} \\
\text { assumed }\end{array}$ & & & -1.397 & 125.17 & .165 & -.168 & .121 \\
\hline
\end{tabular}

As can be shown in Table 10, the factor "student-preference" is different in terms of gender. It implies that males are slightly lower the reasoning "student-preference" $(M=3.82, S D=0.57)$ than females $(M=4.14, S D=0.65)$ and the difference is statically significant $\mathrm{t}(127)=-2.98, p<0.05$. Similarly, factor 2 "teacher and subject" is also different between males and females. The females largely reasoned "teacher and subject" as a cause of their absence $(M=4.07, S D=0.53)$ than males $(M=3.86$, $S D=0.54)$ and the difference is significant $\mathrm{t}(127)=-2.25, p<0.05$. All other factors are not different in term of gender: physical and mental capabilities- $t(121.7)=-1.761, p>$ 0.05 ; non-collegiate- $t(127)=-0.968, p>0.05$; classroom facility- $t(123.18)=-0.129$, $p>0.05$; and personal $\mathrm{t}(127)=-1.40, p>0.05$.

\section{Discussion}

The present study aims to identify the reasons for students' absenteeism. Based on the data that were garnered from 129 Advanced level students, the results revealed a sixfactor that causes students' absenteeism at school. The first factor is studentpreference. The factor is predominantly focusing on students' choice of not attending the school. For instance, students prefer not to go to school for preparing their term exams. The second factor is the teacher and the subject. The factor clearly shows that students are not attending the school because of teacher and subject related matters. For example, students will not attend school if teachers and subjects are boring. Another interesting example is that the student is not attending the school because the teacher is targeting him/her. The third reason for the Students' absenteeism is physical and mental capabilities. For instance, following two occasions students are not attending the school: 'I can't concentrate in class because of feeling sleepy or tired' and 'I can't wake up early due to late night sleep'. Non-Collegiate is the fourth reason for not attending the school. The factor implies that students fail to attend the school owing to their greater involvement in extracurricular activities such as sports. The 
fifth factor, called classroom facility, explains that students are not attending the school because of insufficient facilities at school. Some examples are 'students don't like to attend school because of the uncomfortable sitting arrangement overcrowding, poor ventilation and poor illumination in the classroom. The last reason for the students' absenteeism is a personal factor. The factor includes students' sickness and their mismatch in the subject selection. The mean scores of the six factors clearly show students' agreeableness on each factor: Non-collegiate $(\mathrm{M}=4.10)$, student-preference $(\mathrm{M}=3.97)$, teacher and subject $(\mathrm{M}=3.96)$, personal $(\mathrm{M}=3.95)$, physical and mental capabilities $(\mathrm{M}=3.90)$, and classroom facility $(\mathrm{M}=3.71)$. In overall, the present study found six reasons for the students' absenteeism and the findings are in line with some previous seminal studies (BinSaeed et al., 2009; Dashputra et al., 2015; Haertel et al., 1981; Rao et al., 2016). The present study made many theoretical and practical implications.

\section{Theoretical and Practical Implications}

The current study made a theoretical contribution by identifying the six novel factors contributing to students' absenteeism. The field of education has suffered from a death of the studies in the area of students' absenteeism and thus the present has expanded earlier studies (see Bin Saeed et al., 2009; Dashputra et al., 2015; Rao et al., 2016). As we have discussed earlier, the students' absenteeism is country-culture specific nature, the novel contribution that the study made by examining the reasons for the students' absenteeism in a neglected country, Sri Lanka. Therefore, country-specific inputs advance the extant literature in the field of education. Besides, theoretical contributions, the study has many practical implications. The principals, zonal directors, teachers and the government should pay attention to reduce the students' absenteeism. Most importantly, the factors contributing to students' absenteeism have been related to students' academic performance. For instance, the lack of attendance is a major reason for students' poor performance (Park \& Kerr, 1990), physical environment of the classroom and classroom facilities are linked to lower performance, and low ventilation rates in classrooms significantly reduces the pupils' attention and vigilance, and negatively affect memory and concentration (Taylor \& Vlastos, 2009). Therefore, school administration should pay much care in designing and implementing strategies for alleviating the students' poor attendance. For example, punishment for absenteeism further aggravates the situation and sometimes students stay away from school altogether to avoid the sanctions associated with late arrival and absenteeism (Balfanz \& Byrnes, 2012). There is a possibility that the 
teacher could specifically increase student attendance by utilizing active learning methods and providing timely feedback to students on their course performance. We have identified several possible reasons for this absence. These reasons vary from the more 'valid' reasons, such as illness to less 'valid' reasons, such as sleeping. Therefore, the best mechanism for controlling students' absenteeism is timely required to uplift the standard of education.

Small sample size and common method variance are the major limitations of the present study. Therefore, future studies should focus on a large pool of participants with a longitudinal time horizon. Moreover, scholars should also replicate the studies in similar Asian countries across varying nature of schools. The present study warrants further in-depth qualitative studies in the area of students' absenteeism. On balance, the present study is vital from the theoretical and practical perspectives.

\section{References}

Balfanz, R., \& Byrnes, V. (2012). Chronic absenteeism: Summarizing what we know from nationally available data. Baltimore: Johns Hopkins University Center for Social Organization of Schools, 1(1), 1-46.

Bati, A. H., Mandiracioglu, A., Orgun, F., \& Govsa, F. (2013). Why do students miss lectures? A study of lecture attendance amongst students of health science. Nurse education today, 33(6), 596-601.

Belita, A., Mbindyo, P., \& English, M. (2013). Absenteeism amongst health workers-developing a typology to support empiric work in low-income countries and characterizing reported associations. Human resources for health, 11(1), 11-34.

BinSaeed, A. A., al-Otaibi, M. S., al-Ziyadi, H. G., Babsail, A. A., \&Shaik, S. A. (2009). Association between student absenteeism at a medical college and their academic grades. JIntAssoc Med SciEduc, 19(4), 155-159.

Burke, L. A. (2010). Absenteeism in undergraduate business education: A proposed model and exploratory investigation. Decision Sciences Journal of Innovative Education, 8(1), 95-111.

Burke, P. J. (2015). Re/imagining higher education pedagogies: Gender, emotion and difference. Teaching in Higher Education, 20(4), 388-401.

Cattell, R. B. (1966). The scree test for the number of factors. Multivariate behavioral research, 1(2), 245-276. 
Dashputra, A., Kulkarni, M., Chari, S., \& Date, A. (2015). Medical students' absenteeism in class: reasons and remedies. Journal of Educational Research and Studies January, 3(1), 24-29.

Devadoss, S., \& Foltz, J. (1996). Evaluation of factors influencing student class attendance and performance. American Journal of Agricultural Economics, 78(3), 499-507.

Fernandes, L., Maley, M., \& Cruickshank, C. (2008). The impact of online lecture recordings on learning outcomes in pharmacology. J IntAssoc Med SciEduc, 18(2), 62-70.

Fisher, R., \& Larkin, S. (2008). Pedagogy or ideological struggle? An examination of pupils' and teachers' expectations for talk in the classroom. Language and Education, 22(1), 1-16.

Gump, S. E. (2006). Guess who's (not) coming to class: Student attitudes as indicators of attendance. Educational Studies, 32(1), 39-46.

Haertel, G. D., Walberg, H. J., \&Haertel, E. H. (1981). Socio - psychological environments and learning: A quantitative synthesis. British educational research journal, 7(1), 27-36.

Hair, J.F., Black, W.C., Babin. B.J. \& Anderson, R.E (2014), Multivariate Data Analysis (7thed.), Pearson, England.

Henry, K. L. (2007). Who's skipping school: Characteristics of truants in 8th and 10th grade. Journal of school health, 77(1), 29-35.

Kube, B. A., \&Ratigan, G. (1992). Does your school have a clue?: Putting the attendance policy to the test. The Clearing House, 65(6), 348-350.

Lin, T. C. (2010). Does a student's preference for a teacher's instructional style matter? An analysis of an Economic approach,'. Economics Bulletin, 30(2), 1320-1332.

Massingham, P., \& Herrington, T. (2006). Does attendance matter? An examination of student attitudes, participation, performance and attendance. Journal of universityteaching \& learning practice, 3(2), 82-103.

McElroy, K. A. (2003). The Effect of Attendance on Grade for First Year Economics Students in University College Cork. The Economic and Social Review, 34(3), 311-326.

Paisey, C., \&Paisey, N. J. (2004). Student attendance in an accounting module reasons for non - attendance and the effect on academic performance at a Scottish University. Accounting education, 13(1), 39-53. 
Park, K. H., \& Kerr, P. M. (1990). Determinants of academic performance: A multinomial logit approach. The Journal of Economic Education, 21(2), 101-111.

Rao, B. T., Valleswary, K., Nayak, M. S. D. P., \& Rao, N. L. (2016). Reasons for Absenteeism among the Undergraduate Medical Students Attending for Theory Classes in Rajiv Gandhi Institute of Medical Sciences (RIMS) Ongole, Prakasam District of Andhra Pradesh: A Self Review. IOSR Journal of Research \& Method in Education (IOSR-JRME), 6, 11-19.

Roby, D. E. (2004). Research On School Attendance And Student Achievement: A Study Of Ohio Schools. Educational Research Quarterly, 28(1), 3-16.

Rodríguez, L. F., \&Conchas, G. Q. (2009). Preventing truancy and dropout among urban middle school youth: Understanding community-based action from the student's perspective. Education and urban society, 41(2), 216-247.

Ruiz, J. G., Mintzer, M. J., \& Leipzig, R. M. (2006). The impact of e-learning in medical education. Academic medicine, 81(3), 207-212.

Savage, T. V. (1999). Teaching self-control through management and discipline. Allyn and Bacon.

Schmulian,A., \& Coetzee, S. (2011). Class absenteeism: reasons for non-attendance and the effect on academic performance. Accounting Research Journal, 24(2), 178-194.

Stewart, S. C., Evans, W. H., \& Kaczynski, D. J. (1997). Setting the stage for success: Assessing the instructional environment. Preventing School Failure: Alternative Education for Children and Youth, 41(2), 53-56.

Taylor, A., \&Vlastos, G. (2009). Linking architecture and education: Sustainable design for learning environments. Albuquerque: University of New Mexico Press

Teasley, M. L. (2004). Absenteeism and truancy: Risk, protection, and best practice implications for school social workers. Children \& Schools, 26(2), 117-128.

Wadesango, N., \&Machingambi, S. (2011). Causes and structural effects of student absenteeism: a case study of three South African Universities. Journal of Social Sciences, 26(2), 89-97.

Walker, H., Colvin, G., \& Ramsey, E. (1996). Antisocial behavior in school: Strategies and best practices. Behavioral Disorders, 21(3), 253-255.

Williams, L. L. (2002). Student absenteeism and truancy: Technologies and interventions to reduce and prevent chronic problems among school-age children. Action Research Exchange, 1(1), 1-14.

Zahrah, I. (2016). School dropouts: Implications for social advancement. Retrieved from Daily news: http://dailynews.lk/2016/06/02/features/83420 